\title{
Isolation and Characterization of Tomato Leaf Phyllosphere Methylobacterium and their Effect on Plant Growth
}

\author{
M. Senthilkumar ${ }^{1 *}$ and R. Krishnamoorthy ${ }^{2}$ \\ ${ }^{1}$ Department of Agricultural Microbiology, Tamil Nadu Agricultural University, \\ Coimbatore-641 003, Tamil Nadu, India \\ ${ }^{2}$ Department of Agricultural Microbiology, Agricultural College and Research Institute, \\ Madurai 625 104, Tamil Nadu Agricultural University, Tamil Nadu, India \\ *Corresponding author
}

\begin{tabular}{l} 
K e y w or d s \\
$\begin{array}{l}\text { Methylobacterium sp., } \\
\text { Tomato, Phyllosphere } \\
\text { bacteria, Plant growth } \\
\text { promotion. }\end{array}$ \\
Article Info \\
$\begin{array}{l}\text { Accepted: } \\
17 \text { September } 2017 \\
\text { Available Online: } \\
10 \text { November } 2017\end{array}$ \\
\hline
\end{tabular}

A B S T R A C T

Phyllosphere methylotrophic bacteria from tomato leaves were isolated using selective Ammonia Mineral Salt (AMS) medium. Totally thirty two epiphytic bacterial isolates were selected based on their colony morphology and distinct pigmentation. All the isolates tested were Gram negative, rod shaped and positive for urease, catalase and oxidase activities. The preliminary screening of five randomly selected strains under in vitro for plant growth promoting characteristics and evaluated for their beneficial effects on the early growth of tomato showed positive for nitrogen fixation, ACC deaminase, siderophore and phytohormone productions were chosen for further studies. An in vitro experiment was conducted with 4 selected Methylobacterium spp. to evaluate their effect on tomato seed germination and vigor index. Among the isolates tested, Mt-Tm-13 had significantly increased the seed germination percentage (100\%) earliness in radical emergence and vigor index. Plant inoculation studies indicated that Methylobacterium spp. strains provided a significant beneficial effect to the plants. In pot culture experiment, foliar application of Methylobacterium spp. (1\% v/v concentration) showed that the inoculated plants had significant plant growth, biomass as well as yield attributes. The present study suggests that the Methylobacterium isolates may be used as bio-inoculants for sustainable tomato cultivation.

\section{Introduction}

The criticality of the interaction between plants and microorganisms to agricultural output is increasingly recognized. The role of microorganisms in plant growth promotion, nutrient management and disease control is well known. These beneficial microorganisms colonize the rhizosohere/endorhizosphere of plants and promote growth of the plants through various direct and indirect mechanisms (Saxena et al., 2005). Aerial part of plants are termed as phyllosphere, and the inhabitants are called epiphytes. The overall microbiota in this ecosystem is thus sufficiently large to influence their hosts at the level of the individual plants. Bacteria are by far the most numerous colonists of leaves, often being found in numbers averaging $10^{6}$ to $10^{7}$ cells $\mathrm{cm}^{-2}$ (up to $10^{8}$ cells $\mathrm{g}^{-1}$ ) of leaf (Andrews and Harris, 2000). Clearly, in aggregate, these bacteria are sufficiently numerous to contribute in many processes of importance to global processes, as well as to 
the behavior of the individual plants on which they live.

It is believed that the phyllosphere is dominated by a few bacterial genera. Pseudomonas, Xanthomonas, Bacillus, Erwinia, and Methylobacterium spp. are detected most frequently (Thompson et al., 1993). However, many more taxa are present at low abundance and cultivation-independent studies indicated that bacterial communities on leaf surfaces can be expected to be much more complex than previously thought (Lambais et al., 2006). The vast majority of phyllosphere bacteria is believed to live as commensal organisms without harmful or beneficial effects for the host plant. Little is known about the role of these abundantly occurring bacteria in the phyllosphere ecosystem. On the contrary, a number of bacterial isolates are known to exhibit a plantbeneficial effect. An example for beneficial phyllosphere bacteria, which are known to directly stimulate plant growth, are the pinkpigmented facultative methylotrophs (PPFM).

Methylobacterium spp. colonize in the plant phyllosphere and endosphere, comprising one of the dominant groups in each of these habitats (Pirttila et al., 2005). They are capable of using the plant-derived, reduced one-carbon compound methanol as sole source of carbon and energy (AbandaNkpwatt et al., 2006, Sy et al., 2005). In addition, the pink pigmentation is thought to protect the bacteria from damage by solar radiation during epiphytic growth. The association between Methylobacterium spp. and host plants varies from strong or symbiotic (Jourand et al., 2004) to weak or epiphytic (Omer et al., 2004) and to intermediate or endophytic (Lacava et al., 2004). Interestingly, Methylobacterium-plant association in the phyllosphere is not highly genotype specific (Knief et al., 2010). These bacteria evidently have an intimate association with plants, as they promote plant growth and development by production of phytohormones auxins and cytokinins, which benefit the germination of seeds, and plant growth and development (Ivanova et al., 2001) and ACC deaminase activity (Madhaiyan et al., 2007). Therefore Methylobacterium strains may be useful for the wide range of crops as microbial agents in sustainable agriculture. Abanda-Nkpwatt et al., (2006) reported about a Methylobacterium extorquens strain that promotes growth of various plant seedlings, while Hornschuh et al., (2002) isolated two Methylobacterium strains that positively affect growth of Funaria mosses. Moreover, it was shown for several PPFMs that they produce plant hormones - auxins and cytokines - in vitro (Ivanova et al., 2001, Omer et al., 2004). This strongly suggests that plant hormones produced by phyllosphere bacteria are responsible for plant-growth promoting effects.

Tomato is one of the popular vegetables of great commercial value and is used in various forms. Among them major production countries are China, EU, India, US and Turkey, with China accounting for $31 \%$ of the total world production followed by India. In India it occupying an area of 791 thousand ha, with production of 17398 thousand tons with an average yield of 22 t/ha (Horticulture statistics data, 2014-15 Government of India). This crop is gaining importance both in developing and developed countries and efforts are being made for the quality and quantity production of this commodity (Mahajan and Singh, 2006). It is well known fact that increased dependence on agro chemicals including fertilizers has led to several ill effects on the environment and also results in decrease of soil fertility. Application of organic manure plays an important role on yield and its attributes as well as nutrient uptake and directly increase the soil physical 
condition. Use of biofertilizer and organic manure in agriculture is becoming popular nowadays for not only in order to reduce the cost of chemical fertilizers but also to decrease the adverse effects of chemical fertilizers on soil and plant environment and to ensure more crop productivity.

The present study was designed to explore the various responses of tomato plants to foliar application of different Methylobacterium strains on tomato crops under in vitro conditions.

\section{Materials and Methods}

Healthy and asymptomatic 2-3 fresh leaves were collected from 60 days old tomato plants (variety PKM 1) grown in orchard of Tamil Nadu Agricultural University, Coimbatore, South India. Leaves were collected at 9:00A.M, stored in sterile propylene bags at $4^{\circ} \mathrm{C}$ and analyzed within $24 \mathrm{~h}$ after their collection. Samples were taken from $3^{\text {rd }}$ leaf position from each plant were collected and cleaned under running tap water to remove debris and then air dried. Each leaf was divided into two equal parts with one part from the apex and one from the base was selected for analysis.

Tomato leaves were leaf imprinted in the Ammonia Mineral Salt (AMS) media for 1 minute and the plates were incubated at $30^{\circ} \mathrm{C}$ for 7days till a distinct pink color colony was appeared along the leaf imprinting area. From each plate, based on distinct colony morphological features bacterial colonies were chosen at random.

The isolates were maintained on AMS agar slants at $4^{0} \mathrm{C}$ and also as $30 \%$ glycerol stocks at $-80^{\circ} \mathrm{C}$. Biochemical characterization of the Methylobacterium isolates was carried out according to Bergeys Manual of Determinative Bacteriology.
Plant growth promoting traits of the isolates

\section{Nitrogen fixing ability}

Methylobacterium spp. were tested for their growth in nitrogen free medium. The bacterial isolates were grown in AMS broth without addition of $\mathrm{NH}_{4} \mathrm{Cl}$ and incubated at $28^{\circ} \mathrm{C}$ for 10 days and bacterial growth was observed as qualitative evidence of the atmospheric nitrogen fixation.

The growth measurement was taken in a UVvis spectrophotometer (Cary 50 Bio, varian) at $660 \mathrm{~nm}$ and expressed as - no growth $(<$ $0.1 \mathrm{OD}) ;+(0.1$ to 0.3$)$ and $++(0.3$ to 0.5$)$.

\section{ACC deaminase activity}

Screening for ACC deaminase activity of epiphytic Methylobacterium sp. isolates were done as mentioned by (Penrose and Glick, 2003). All the isolates were grown in $10 \mathrm{ml}$ of AMS medium incubated at $28^{\circ} \mathrm{C}$ at $120 \mathrm{rpm}$ for 4 to 5 days and cells were harvested by centrifugation at $3000 \mathrm{~g}$ for $5 \mathrm{~min}$, washed twice with sterile $0.1 \mathrm{M}$ Tris- $\mathrm{HCl}(\mathrm{pH} 7.5)$, resuspended in $1 \mathrm{ml}$ of $0.1 \mathrm{M}$ Tris $\mathrm{HCl}(\mathrm{pH}$ 7.5) and spot inoculated on petri plates containing modified DF minimal medium supplemented with $3 \mathrm{mM}$ ACC as sole nitrogen source.

Plates containing only DF salts minimal medium without ACC as negative control and with $\left(\mathrm{NH}_{4}\right)_{2} \mathrm{SO}_{4} \quad(0.2 \% \quad \mathrm{w} / \mathrm{v})$ as positive control. The plates were incubated at $28^{\circ} \mathrm{C}$ for 72 h. Growth of isolates on ACC supplemented plates was compared to negative and positive controls and was selected based on growth by utilizing ACC as sole nitrogen source. The presence or absence of growth indicate positive for ACC deaminase activity and negative for ACC deaminase activity respectively. 


\section{Siderophore production}

The production of siderophore by the bacterial isolates were performed qualitatively by plate assay (Schwyn and Neilands, 1987). Seventy two hour old cultures were streaked on the succinate medium amended with tertiary complex Chrome azurol S (CAS) / $\mathrm{Fe}^{3+} /$ hexadecyl trimethyl ammonium bromide as an indicator. The result was scored either positive or negative to this test, based on the colour change of the medium from blue to fluorescent yellow while no colour change was marked as absence of siderophore production.

\section{Endoglucanase activity of Methylobacterium spp.}

The epiphytic Methylobacterium spp. isolates were point inoculated using sterile tooth pick on Kim Wimpeny medium plates amended with and without D-glucose containing $1 \%$ carboxymethyl cellulose. After 3 days of incubation at $30^{\circ} \mathrm{C}$, the plates were flooded in $0.1 \%$ congo red for $30 \mathrm{~min}$. followed by $1 \mathrm{M}$ $\mathrm{NaCl}$ as destaining solution for $10 \mathrm{~min}$. Endoglucanase activity was determined by the appearance of clear yellow zones around the colonies (Reinhold-Hurek et al., 1993).

\section{Estimation and quantification of phytohormones}

\section{Cytokinin}

\section{Extraction of cytokinin}

The epiphytic Methylobacterium spp. isolates were grown in AMS liquid medium for 7 days at $30^{\circ} \mathrm{C}$ in a rotary shaker at $250 \mathrm{rpm}$. The overgrown culture was centrifuged at 12,000 rpm for $30 \mathrm{~min}$. and the supernatant was extracted twice with equal amount of nbutanol using separating funnel and the fractions were evaporated in petriplate at room temperature. After evaporation, the cytokinin fractions were dissolved in $2 \mathrm{ml}$ of $100 \%$ absolute methanol (HPLC grade) followed by filter sterilization using $0.2 \mu \mathrm{m}$ membrane filter.

\section{Quantification of cytokinin}

Filter sterilized cytokinin fractions $(20 \mu \mathrm{l})$ were injected into high performance liquid chromatography (HPLC). Analysis was performed using a $10 \mu \mathrm{m}$ particle size reverse phase column (C18) with a solvent gradient of 30 per cent methanol in water at a flow rate of $1.5 \mathrm{ml} \mathrm{min}^{-1}$ with operating pressure of 300 psi. Quantification of cytokinin compounds in the sample was compared to the retention time with peak height of chemical grade benzyl adenine purine (BAP), kinetin, zeatin, zeatin riboside and trans zeatin $\mathrm{HCl}$ (Sigma grade). Substances were quantified by integrating the areas under the peaks using UV detector at $254 \mathrm{~nm}$.

\section{Auxin}

\section{Extraction of IAA}

The amount of indole compounds in the culture liquid of Methylobacterium sp. isolates was determined in the logarithmic phase after removing cells by centrifugation at $10,000 \mathrm{x} \mathrm{g}$ for $30 \mathrm{~min}$. Auxins were extracted with an equal volume of ethyl acetate from the culture filterate acidified to $\mathrm{pH}$ of 2.5-3.0 with $0.1 \mathrm{~N} \mathrm{HCl}$. Then the extracts were dried, the residues were dissolved in 80 per cent methanol and the auxin present in the samples were separated by HPLC.

\section{Quantification of IAA}

The ethyl acetate fractions were evaporated and the sediment was dissolved in $3 \mathrm{ml}$ absolute methanol (Ivanova et al., 2001). The 
membrane filtered extract of $10 \mu 1$ was then injected into HPLC (Shimadzu, Japan). Analysis was performed using a $10 \mu \mathrm{m}$ particle size reverse phase column $(\mathrm{C} 18)$ with a solvent gradient of 30 per cent methanol in water at a flow rate of $1.5 \mathrm{ml} \mathrm{min}{ }^{-1}$ with the operating pressure of $300 \mathrm{psi}$. The standard solution of IAA was prepared in 10 to $50 \mu \mathrm{g}$ concentrations, from that $10 \mu \mathrm{l}$ was injected into HPLC. Substances were quantified by integrating the areas under the peaks using $\mathrm{UV}$ detector at $254 \mathrm{~nm}$. The quantity of different indole compounds in the sample was calculated by comparison of peak height and retention time of respective standards.

\section{Crop response studies}

\section{Selection and preparation of bacterial inoculum}

Based on the phytohormones synthesis (zeatin, kinetin, BAP and IAA) three strains (Mt-Tm 8, 13 and '14) were selected to test its ability in improving the tomato crop growth and development. Selected isolates were grown in $25 \mathrm{ml}$ AMS broth at $30^{\circ} \mathrm{C}$ for 10days. The cell pellets were washed twice with sterile $0.03 \mathrm{M} \mathrm{MgSO}_{4}$ and resuspended in phosphate buffer to an OD of $0.15 \pm 0.02$ at $600 \mathrm{~nm}$ to avoid the influence of growth medium, and used as inocula for seedling vigor assay under gnotobiotic conditions.

\section{Surface sterilization of seeds}

Tomato (variety PKM-1) seeds were obtained from Horticultural College, Tamil Nadu Agricultural University, Coimbatore, Tamil $\mathrm{Nadu}$, India. Seeds were surface-sterilized as described by Senthilkumar et al., (2009). Briefly seeds were surface sterilized with $70 \%$ ethanol for $1 \mathrm{~min}$ followed by $1 \%$ sodium hypochlorite $(\mathrm{NaOCl})$ for $20 \mathrm{~min}$, and washed thoroughly with sterile milli-Q water several times. From the last washings, one $\mathrm{ml}$ of the aliquot was checked for the presence of bacteria by serial dilution technique and there was no bacterial growth indicating the complete surface sterilization of the seeds. Bacterial suspensions in sterile distilled water $\left(10^{8} \mathrm{cfu} \mathrm{ml} l^{-1}\right)$ were used for seed imbibition; control seeds were treated with $0.03 \mathrm{M}$ $\mathrm{MgSO}_{4}$. The sterilized seeds were soaked in the inoculum for 15 minutes and then shade dried for 10-15minutes before sowing.

\section{Seedling vigor assay}

After surface sterilization, tomato seeds (2030 seeds) were treated with respective bacterial isolates as mentioned above. Control seeds were incubated in sterile distilled water for the same period. Germination tests were carried out by the paper towel method. The germination paper was soaked in distilled water, 15-20 bacterially treated seeds and untreated seeds were placed on paper towels, rolled and wrapped with polythene to prevent drying, and incubated at above mentioned conditions. After 15days, the towels were unrolled and the number of seeds that had germinated was counted. On the same day, seedling vigor was analyzed using the method of Abdul Baki and Anderson (1973). The lengths of roots and hypocotyls of all the individual seedlings were measured. The vigor index (VI) was calculated using the formula VI $=$ (mean root length + mean hypocotyl length) $x \%$ germination. The experiment was repeated twice.

\section{Greenhouse experiment}

Study was conducted to assess the foliar application of Methylobacterium spp. on the yield of tomato in potted soil conditions. Three to five bacterized seeds were sown into plastic pots having diameter $45 \mathrm{~cm}$ and containing $10 \mathrm{~kg}$ sterile soil mixture having the physiochemical properties of $\mathrm{pH} 7.3$, EC $1.3 \mathrm{dSm}^{-1}$, organic carbon $3.78 \mathrm{~g} \mathrm{~kg}^{-1}$ 
available $\mathrm{N} 82 \mathrm{mg} \mathrm{kg}^{-1}$, available P $9.4 \mathrm{mg} \mathrm{kg}$ ${ }^{1}$ and potassium $260 \mathrm{mg} \mathrm{kg}^{-1}$. The pots were pre irrigated to the field capacity before sowing. The soil compost used has a composition of soil: sand: compost in a ratio of $2: 1: 1$. There were 8 treatments in all. Where, $\mathrm{T} 1=$ un-inoculated control, $\mathrm{T} 2=$ water spray, $\mathrm{T} 3=\mathrm{Mt}-\mathrm{Tm}-8$ foliar application $@ 0.5 \%, \mathrm{~T} 4=\mathrm{Mt}-\mathrm{Tm}-8$ foliar application @ 1.0\%, T5= Mt-Tm-13 foliar application $@ 0.5 \%, \mathrm{~T} 6=\mathrm{Mt}-\mathrm{Tm}-13$ foliar application @ 1.0\%, T7= Mt-Tm-14 foliar application $@ 0.5 \%, \mathrm{~T} 8=\mathrm{Mt}-\mathrm{Tm}-14$ foliar application $@ 1.0 \%$. Fifteen days after sowing and during peak flowering stage foliar application of Methylobacterium spp. was done. The seed germination was noted on the $12^{\text {th }}$ day of sowing. The pots were irrigated routinely. The experiment was conducted in a completely randomized block design and each treatment was replicated five times. Seedling growth, phenology, were recorded. Two plants from each pot were randomly selected for recording the data. The whole plant dry weight $\left(\mathrm{g}\right.$ plant $\left.^{-1}\right)$, plant height $(\mathrm{cm})$, number of leaves per plant, number of fruits per plant, yield per plant (g), average fruit weight per plant, chlorophyll and protein were observed. Relative water content and proline content was measured as given in Quilambo, (2014).

\section{Data analysis}

The data were measured and subjected to oneway analysis of variance (ANOVA) using SPSS software package for Windows (SPSS, version 10.0). Where there was statistical significance $(P=0.05)$, the mean values were further separated using the Duncan's multiple range test (DMRT).

\section{Results and Discussion}

Most microbes inhabiting plant-related niches have neutral or beneficial roles in plant health and development (Philippot et al., 2013).
Microorganisms can affect agricultural productivity, for instance by assisting and controlling nutrient availability/acquisition and promoting stress tolerance (Kavamura et al., 2013). Most of the research on this topic has focused on the functional roles of single microbial groups (e.g., specific species or organisms from the same genera) associated with plants, mostly because of methodological limitations to assess non-culturable microbial groups (Andreote et al., 2009). Examples of these inferences are related to specific microbial groups able to promote plant growth, such as nitrogen-fixing bacteria (Raymond et al., 2004) and mycorrhizaforming fungi (Chagnon et al., 2013). The cascade of events that occurs after a bacterial cell recognizes host plant results in major changes in cellular metabolism, including the accumulation of several secondary metabolites (Hahlbrock et al., 2003). Such physiological changes can modulate the growth and development of the plant. However, considering their complexity, these mechanisms and networks are still far from being elucidated. Therefore, different studies have been conducted with the aim of uncovering these mechanisms.

Plant growth stimulation by epiphytic bacteria is largely due to phytohormone production, and several studies have been reported the interaction of Methylobacterium species with different plant species by regulating phytohormone production (Schauer and Kutschera, 2011). Methylobacterium strains have been reported to produce phytohormones such as cytokinins and auxins (Pirttila et al., 2005), which promote cell division and elongation, respectively. A total of 32 endophytic bacterial colonies were characterized for colony morphology, cell shape, Gram reaction and pigment production followed by biochemical characters (data not shown). All the Methylobacterium isolates were rod shaped and Gram negative. The 
colony morphology varied from circular, blend, raised, convex, and low convex and pulvinate. The isolates also exhibited varied colony colours viz., whitish pink, light pink, orangish pink, pink and dark pink (data not shown). In static culture, all the selected strains formed a pink surface ring and/or pellicle, this showed that the strains tested were strict aerobes and were tentatively identified as Methylobacterium sp. All the strains failed to degrade or hydrolyze casein, starch, gelatine and cellulose. None of the isolates possessed lipolytic activity. All the strains showed positive for catalase, oxidase and urease activity. The indole production, methyl red and Voges Proueskauer tests were negative in all the strains tested. The epiphytic isolates did not reduce nitrate to nitrite and absence of denitrification and $\mathrm{H}_{2} \mathrm{~S}$ production was also noticed In addition, they can form biofilms (Rossetto et al., 2011) and use methylotrophic metabolism as an adaptive advantage during plant host colonization (Sy et al., 2005). Members of the Methylobacterium genus occupy different habitats due to their great phenotypic plasticity, including soil, water, leaf surfaces, nodules, grains, and air (Madhaiyan et al., 2012).

\section{Assessing the PGPR traits}

During interactions with plants, $M$. nodulans and $M$. radiotolerans have been reported to be involved in nitrogen fixation and nodule formation (Sy et al., 2001), while other Methylobacterium species may be related to phytohormone production (Meena, 2012) or interacting with plant pathogens (Lacava et al., 2004), promoting plant growth (Madhaiyan et al., 2006) and inducing higher photosynthetic activity but few reports were related to PGP epiphytic bacteria from tomato plant tissues (Shen et al., 2012). Five isolates were randomly selected and tested for its abilities to promote plant growth. Almost all selected Methylobacterium isolates exhibited more than three plant growth promoting traits. These results showed that the microorganisms isolated from similar environment showed similar plant growth promoting character. This can be explained as the regional characteristics and environmental selectivity (Sheng et al., 2011). Firstly, their ability to produce cytokinins and indole-3-acetic acid (IAA) were tested. All five Methylobacterium isolates produced significant amounts of cytokinins like zeatin, kinetin, benzyl amino purine (BAP) and IAA except Mt-Tm-9 and Mt-Tm-10 did not synthesis BAP and kinetin respectively (Table 1). The biosynthesis of zeatin was significantly higher for Mt-TM-13 which produced $4.94 \mu \mathrm{g} \mathrm{ml}^{-1}$, followed by Kinetin and BAP. Several reports indicated that even strains belonging to the same genus produced different amounts of IAA, because it was affected by culture conditions, growth stage or substrates (Ahmad et al., 2008). It is a well-established fact that IAA regulates several cellular and plant growth processes (Lambrecht et al., 2000). Similarly, the bacterial isolates obtained from Maize (Montañez et al., 2012), Tomato (Rashid et al., 2012) and Wheat (Durán et al., 2014) were able to produce IAA. Growth on $\mathrm{N}-$ free medium, ACC deaminase activity, production of siderophore on a R2A-CAS medium were assayed. Variable results were obtained among the five isolates. All isolates formed a halo around the colonies on this medium and were considered to be siderophore positive. Production of sideophore is one of the traits for the bacteria to compete with other bacteria to colonize plant roots and leaf as well as inhibit the pathogens (Ahmad et al., 2008). Loaces et al., (2011) showed that the 11 rice leaf epiphytic isolates were able to produce siderophore, the isolates were belonging to Pantoea and Pseudomonas genera. The $\mathrm{N}_{2}$-fixing ability of bacterial epiphytes was also screened on a $\mathrm{N}_{2-}$ free media. Out of selected five isolates, only 
two isolates (Mt-Tm-10 and 13) showed the capacity to grow in nitrogen-free conditions confirming the significance of potential $\mathrm{N}_{2-}$ fixing ability for endophytic bacteria in the host plant. Except Mt-Tm-10 all isolates showed the endoglucanase activity (Table 2).

\section{Plant response to Methylobacterium spp. isolates application}

\section{Seed Vigor and Seedling Growth}

The purposes of introducing bio-inoclant modulating seed microbiomes is to achieve improvement of a desired agricultural trait such as growth enhancement of the offspring plant. Treatment of seed with beneficial micro-organisms including fungi and bacteria (species of Trichoderma, Pseudomonas, Bacillus, Rhizobia etc.) ameliorates a wide variety of biotic, abiotic, and physiological stresses to seed and seedlings (Mastouri et al., 2010). Inoculation of seeds with such biological agents in combination with priming (Biopriming) potentially able to promote rapid and more uniform seed germination and plants growth (Moeinzadeh et al., 2010) and in several cases, has been reported to enhance and stabilize the efficacy of biological agents (Warren and Bennett, 1999).Seed imbibition with different types of Methylobacterium isolates showed significant variation in the vigor index and germination (Table 3). Tomato seeds imbibed with Methylobacterium isolates at two different concentrations $(0.5 \%$ and $1.0 \%)$ had induced the earliness in radical emergence on $4^{\text {th }}$ day after treatment with more than $90 \%$ seeds showed radical protusion and $100 \%$ germination was attained on 10 days after sowing with Mt-TM-8, and 13 strains. In a report by Long et al., (2008), a Solanum nigrum seedling vigour assay was carried out to screen the epiphytic bacterial isolates for their PGP ability such as on seed germination, root and hypocotyl growth and 37 of 77 isolates increased seedling vigour and 22 isolates significantly enhanced seed germination up to $100 \%$ compared to untreated controls.

Table.1 Screening of epiphytic Methylobacterium spp. for plant growth hormones production

\begin{tabular}{|c|c|c|c|c|}
\hline Strains & Zeatin $\left(\mu \mathrm{g} \mathrm{ml}^{-1}\right)$ & Kinetin $\left(\mu \mathrm{g} \mathrm{ml}^{-1}\right)$ & BAP $\left(\mu \mathrm{g} \mathrm{ml}^{-1}\right)$ & IAA $\left(\mu \mathrm{g} \mathrm{ml}^{-1}\right)$ \\
\hline MtTm8 & $0.12 \pm 0.00$ & $10.1 \pm 0.51$ & $0.16 \pm 0.01$ & $102.3 \pm 1.20$ \\
\hline Mt TM 9 & $0.68 \pm 0.17$ & $1.61 \pm 0.06$ & - & $86.9 \pm 1.20$ \\
\hline MtTm10 & $0.90 \pm 0.11$ & - & $0.12 \pm 0.00$ & $29.8 \pm 0.65$ \\
\hline MtTm13 & $4.94 \pm 0.16$ & $6.03 \pm 0.01$ & $0.14 \pm 0.01$ & $88.1 \pm 1.16$ \\
\hline MtTm14 & $0.65 \pm 0.02$ & $1.04 \pm 0.04$ & $0.11 \pm 0.00$ & $7.64 \pm 0.11$ \\
\hline
\end{tabular}

Table.2 Plant growth promoting activities of epiphytic Methylobacterium spp. isolated from phyllosphere region of tomato

\begin{tabular}{ccccc}
\hline Strains & $\begin{array}{c}\text { Growth in N free } \\
\text { medium }\end{array}$ & $\begin{array}{c}\text { ACC } \\
\text { deaminase }\end{array}$ & $\begin{array}{c}\text { Siderophore } \\
\text { production }\end{array}$ & $\begin{array}{c}\text { Endoglucanase } \\
\text { activity }\left(\mathbf{G l u}^{+}\right)\end{array}$ \\
\hline MtTm8 & - & + & + & + \\
\hline Mt TM 9 & - & - & + & + \\
\hline MtTm10 & + & + & + & + \\
\hline MtTm13 & + & + & + & + \\
\hline MtTm14 & - & + & + & + \\
\hline
\end{tabular}

+ indicates the presence of growth; - indicates the absence of growth; Glu ${ }^{+}$- glucose and N - Nitrogen 
Table.3 Effect of Methylobacterium spp. on tomato seed germination and vigor index

\begin{tabular}{|c|c|c|c|c|c|c|c|c|c|}
\hline \multirow{3}{*}{ Treatments } & \multicolumn{9}{|c|}{ Seedling parameters } \\
\hline & \multirow[t]{2}{*}{$\begin{array}{l}\text { Percentage } \\
\text { of radical } \\
\text { protusion }\end{array}$} & \multirow[t]{2}{*}{$\begin{array}{l}\text { Germination } \\
\% \text { on } 4^{\text {th }} \text { day }\end{array}$} & \multirow[t]{2}{*}{$\begin{array}{l}\text { Germination } \\
\% \text { on } 10^{\text {th }} \\
\text { day }\end{array}$} & \multicolumn{2}{|c|}{$\begin{array}{l}\text { Growth on } 10^{\text {th }} \\
\text { day (Av. } 25 \\
\text { seedlings / } \\
\text { replication) } \\
\left(\mathrm{cm} \text { plant }^{-1}\right) \\
\end{array}$} & \multirow{2}{*}{$\begin{array}{l}\text { Days for } \\
\text { maximum } \\
\text { germinatio } \\
\mathrm{n}\end{array}$} & \multirow{2}{*}{$\begin{array}{l}\text { Vigor } \\
\text { index }\end{array}$} & \multicolumn{2}{|c|}{$\begin{array}{l}\text { Biomass on } 10^{\text {th }} \text { day } \\
\text { (Av. } 25 \text { seedlings/ } \\
\text { replication) }\left(\text { mgplant }^{-1}\right)\end{array}$} \\
\hline & & & & $\begin{array}{l}\text { Shoot } \\
\text { length }\end{array}$ & $\begin{array}{l}\text { Root } \\
\text { length }\end{array}$ & & & $\begin{array}{l}\text { Fresh } \\
\text { wt }\end{array}$ & $\begin{array}{l}\text { Dry } \\
\text { wt. }\end{array}$ \\
\hline $\begin{array}{l}\text { Uninoculated } \\
\text { control }\end{array}$ & 28.50 & 52.5 & 65 & $\begin{array}{c}5.5 \\
( \pm 0.29) \\
\end{array}$ & $\begin{array}{c}4.0 \\
( \pm 0.29) \\
\end{array}$ & 9 & 617.5 & $\begin{array}{c}379.66 \\
( \pm 21.62) \\
\end{array}$ & $\begin{array}{r}75.00 \\
( \pm 6.69) \\
\end{array}$ \\
\hline Water & 64.28 & 79.16 & 86.6 & $\begin{array}{c}6.0 \\
( \pm 0.17) \\
\end{array}$ & $\begin{array}{c}4.0 \\
( \pm 0.00) \\
\end{array}$ & 7 & 866 & $\begin{array}{l}414.33 \\
( \pm 5.46) \\
\end{array}$ & $\begin{array}{r}113.33 \\
( \pm 5.24) \\
\end{array}$ \\
\hline $0.5 \% \mathrm{MtTm} 8$ & 76.19 & 89.16 & 100 & $\begin{array}{c}6.33 \\
( \pm 0.17) \\
\end{array}$ & $\begin{array}{c}4.16 \\
( \pm 0.17) \\
\end{array}$ & 5 & 1049 & $\begin{array}{l}430.66 \\
( \pm 4.63)\end{array}$ & $\begin{array}{c}82.33 \\
( \pm 2.08) \\
\end{array}$ \\
\hline $1.0 \% \mathrm{MtTm} 8$ & 90.47 & 98.3 & 100 & $\begin{array}{c}6.66 \\
( \pm 0.33) \\
\end{array}$ & $\begin{array}{c}4.5 \\
( \pm 0.00) \\
\end{array}$ & 5 & 1116 & $\begin{array}{c}465.66 \\
( \pm 11.41) \\
\end{array}$ & $\begin{array}{r}149.66 \\
( \pm 4.70) \\
\end{array}$ \\
\hline $\begin{array}{l}0.5 \% \mathrm{MtTm} 13 \\
\text { spray }\end{array}$ & 78.57 & 96.83 & 100 & $\begin{array}{c}6.5 \\
( \pm 0.50) \\
\end{array}$ & $\begin{array}{c}4.33 \\
( \pm 0.33) \\
\end{array}$ & 5 & 1083 & $\begin{array}{c}466.33 \\
( \pm 5.90) \\
\end{array}$ & $\begin{array}{r}141.33 \\
( \pm 6.12) \\
\end{array}$ \\
\hline $\begin{array}{l}1.0 \% \text { Mt-Tm-13 } \\
\text { spray }\end{array}$ & 95.23 & 99.16 & 100 & $\begin{array}{c}6.83 \\
( \pm 0.17) \\
\end{array}$ & $\begin{array}{c}4.83 \\
( \pm 0.17) \\
\end{array}$ & 4 & 1166 & $\begin{array}{l}473.33 \\
( \pm 3.38) \\
\end{array}$ & $\begin{array}{r}149.66 \\
( \pm 7.06) \\
\end{array}$ \\
\hline $\begin{array}{l}0.5 \% \text { Mt-Tm-14 } \\
\text { spray }\end{array}$ & 78.57 & 93.33 & 95.83 & $\begin{array}{c}5.83 \\
( \pm 0.17) \\
\end{array}$ & $\begin{array}{c}4.16 \\
( \pm 0.17) \\
\end{array}$ & 6 & 957.34 & $\begin{array}{l}465.66 \\
( \pm 3.38) \\
\end{array}$ & $\begin{array}{r}149.66 \\
( \pm 4.33) \\
\end{array}$ \\
\hline $\begin{array}{l}1.0 \% \mathrm{Mt}-\mathrm{Tm}-14 \\
\text { spray }\end{array}$ & 78.57 & 92.5 & 100 & $\begin{array}{c}6.0 \\
( \pm 0.00) \\
\end{array}$ & $\begin{array}{c}4.33 \\
( \pm 0.17) \\
\end{array}$ & 6 & 1043 & $\begin{array}{l}436.66 \\
( \pm 6.94) \\
\end{array}$ & $\begin{array}{r}126.33 \\
( \pm 5.04) \\
\end{array}$ \\
\hline $\mathrm{CD}$ & 4.28 & 3.42 & 5.08 & 1.3 & 0.2 & 0.9 & 3.1 & 3.9 & 2.0 \\
\hline SEd & 2.21 & 1.6 & 2.39 & 0.6 & 0.08 & 0.51 & 1.7 & 2.06 & 1.12 \\
\hline
\end{tabular}




\section{Int.J.Curr.Microbiol.App.Sci (2017) 6(11): 2121-2136}

Table.4 Effect of Methylobacterium spp. on tomato plant growth and yield

\section{Plant parameters}

\begin{tabular}{|c|c|c|c|c|c|c|c|}
\hline Treatments & $\begin{array}{c}\text { Shoot length at } \\
\text { harvest } \\
\left(\mathrm{cm} \mathrm{plant}^{-1}\right)\end{array}$ & $\begin{array}{l}\text { Root length at } \\
\text { harvest } \\
\left(\mathrm{cm}^{-1 a n t^{-1}}\right)\end{array}$ & $\begin{array}{l}\text { Average number of } \\
\text { fruits (No.plant }{ }^{-1} \text { ) }\end{array}$ & $\begin{array}{l}\text { Average Weight } \\
\text { of individual } \\
\text { fruits / plant (g) }\end{array}$ & $\begin{array}{c}\text { Average } \\
\text { yield/ plant (g) }\end{array}$ & $\begin{array}{l}\text { Dry wt of } \\
\text { plant } \\
\left(\text { g plant }^{-1}\right)\end{array}$ & $\begin{array}{c}\text { Population of } \\
\text { Methylobacterium at the time } \\
\text { of flowering } \\
\text { (cfu g }{ }^{-1} \text { fresh weight of leaf) }\end{array}$ \\
\hline Uninoculated & 79.99 & 55.73 & 6.7 & 29.31 & 178.92 & 46.07 & $22 \times 10^{4}$ \\
\hline control & $( \pm 0.19)$ & $( \pm 0.48)$ & $( \pm 0.30)$ & $( \pm 0.64)$ & $( \pm 3.19)$ & $( \pm 1.16)$ & \\
\hline Water spray & $\begin{array}{r}79.66 \\
( \pm 0.38)\end{array}$ & $\begin{array}{r}54.00 \\
( \pm 2.23)\end{array}$ & $\begin{array}{r}6.7 \\
( \pm 0.10)\end{array}$ & $\begin{array}{r}29.47 \\
( \pm 0.93)\end{array}$ & $\begin{array}{l}193.66 \\
( \pm 1.26)\end{array}$ & $\begin{array}{r}47.05 \\
( \pm 0.98)\end{array}$ & $38 \times 10^{5}$ \\
\hline $0.5 \%$ MtTm8 spray & $\begin{array}{r}80.55 \\
( \pm 2.54)\end{array}$ & $\begin{array}{r}58.44 \\
( \pm 0.44)\end{array}$ & $\begin{array}{c}7.8 \\
( \pm 0.30)\end{array}$ & $\begin{array}{r}31.64 \\
( \pm 0.65)\end{array}$ & $\begin{array}{l}205.94 \\
( \pm 0.53)\end{array}$ & $\begin{array}{r}48.46 \\
( \pm 0.08)\end{array}$ & $49 \times 10^{6}$ \\
\hline $1.0 \% \mathrm{MtTm} 8$ spray & $\begin{array}{r}92.77 \\
( \pm 1.06)\end{array}$ & $\begin{array}{r}61.60 \\
( \pm 1.77)\end{array}$ & $\begin{array}{c}8.2 \\
( \pm 0.10)\end{array}$ & $\begin{array}{r}32.79 \\
( \pm 1.19)\end{array}$ & $\begin{array}{l}238.94 \\
( \pm 1.77)\end{array}$ & $\begin{array}{r}52.86 \\
( \pm 2.48)\end{array}$ & $36 \times 10^{6}$ \\
\hline $\begin{array}{l}0.5 \% \mathrm{MtTm} 13 \\
\text { spray }\end{array}$ & $\begin{array}{r}90.66 \\
( \pm 0.38)\end{array}$ & $\begin{array}{r}60.28 \\
( \pm 1.14)\end{array}$ & $\begin{array}{c}8.0 \\
( \pm 0.33)\end{array}$ & $\begin{array}{r}30.61 \\
( \pm 1.98)\end{array}$ & $\begin{array}{l}236.40 \\
( \pm 2.91)\end{array}$ & $\begin{array}{r}49.13 \\
( \pm 0.26)\end{array}$ & $26 \times 10^{6}$ \\
\hline $\begin{array}{l}1.0 \% \mathrm{MtTm} 13 \\
\text { spray }\end{array}$ & $\begin{array}{c}97.55 \\
( \pm 0.29)\end{array}$ & $\begin{array}{r}62.68 \\
( \pm 1.28)\end{array}$ & $\begin{array}{c}8.8 \\
( \pm 0.30)\end{array}$ & $\begin{array}{r}33.72 \\
( \pm 1.82)\end{array}$ & $\begin{array}{l}257.62 \\
( \pm 1.76)\end{array}$ & $\begin{array}{r}53.85 \\
( \pm 1.92)\end{array}$ & $68 \times 10^{6}$ \\
\hline $\begin{array}{l}0.5 \% \mathrm{MtTm} 14 \\
\text { spray }\end{array}$ & $\begin{array}{r}85.44 \\
( \pm 0.78)\end{array}$ & $\begin{array}{r}58.66 \\
( \pm 1.94)\end{array}$ & $\begin{array}{c}7.7 \\
( \pm 0.57)\end{array}$ & $\begin{array}{c}31.11 \\
( \pm 1.43)\end{array}$ & $\begin{array}{l}222.36 \\
( \pm 3.24)\end{array}$ & $\begin{array}{r}48.07 \\
( \pm 0.80)\end{array}$ & $45 \times 10^{6}$ \\
\hline $\begin{array}{l}1.0 \% \mathrm{MtTm} 14 \\
\text { spray }\end{array}$ & $\begin{array}{r}88.99 \\
( \pm 0.70)\end{array}$ & $\begin{array}{r}60.97 \\
( \pm 1.00)\end{array}$ & $\begin{array}{c}8.0 \\
( \pm 0.38)\end{array}$ & $\begin{array}{r}32.18 \\
( \pm 1.14)\end{array}$ & $\begin{array}{c}237.95 \\
( \pm 14.15)\end{array}$ & $\begin{array}{r}49.52 \\
( \pm 1.14)\end{array}$ & $46 \times 10^{6}$ \\
\hline $\mathrm{CD}$ & 1.8 & 1.24 & 0.51 & 0.67 & 5.18 & 1.1 & \\
\hline SEd & 0.86 & 0.7 & 0.32 & 0,29 & 2.74 & 0.61 & \\
\hline
\end{tabular}


Fig.1 PPFM spray on tomato leaf relative water content and proline content

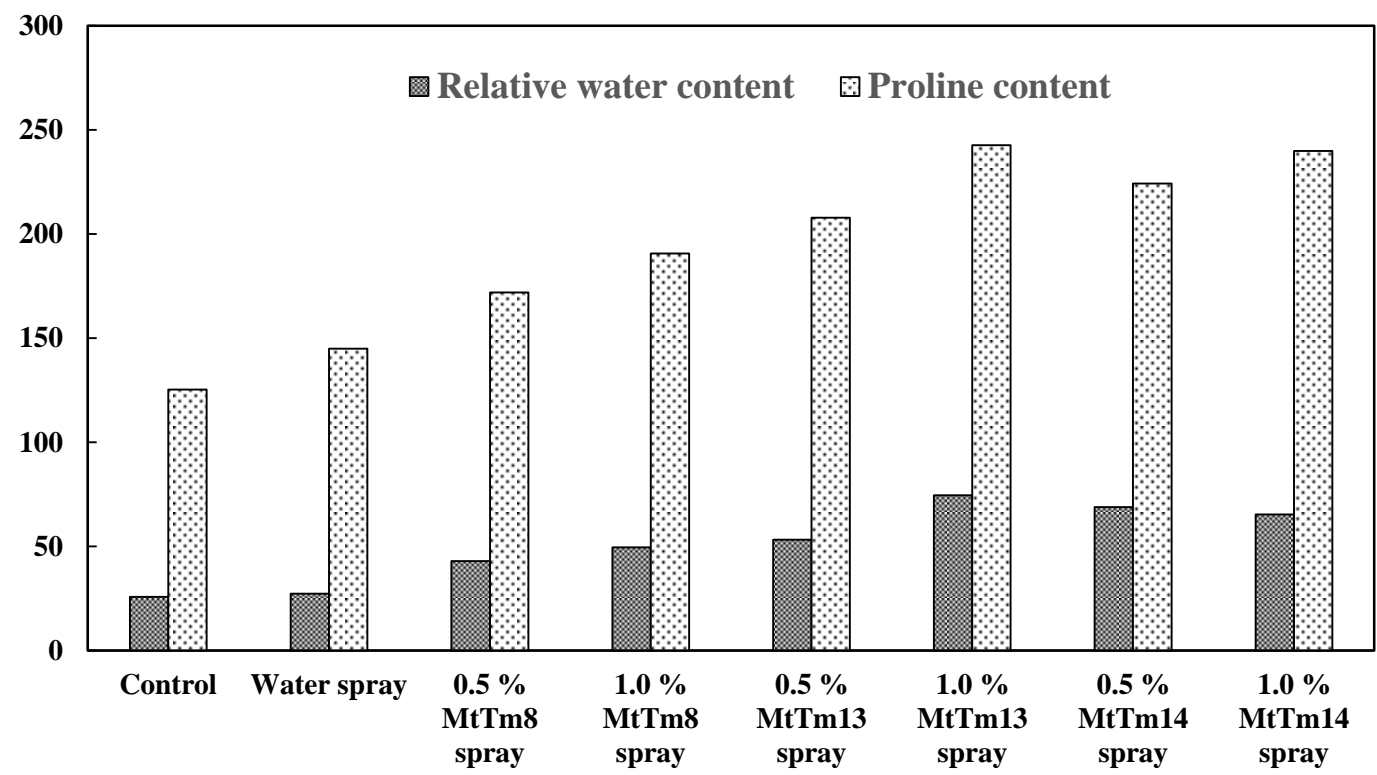

Fig.2 Effect of PPFM spray on physiological parameters of tomato plant

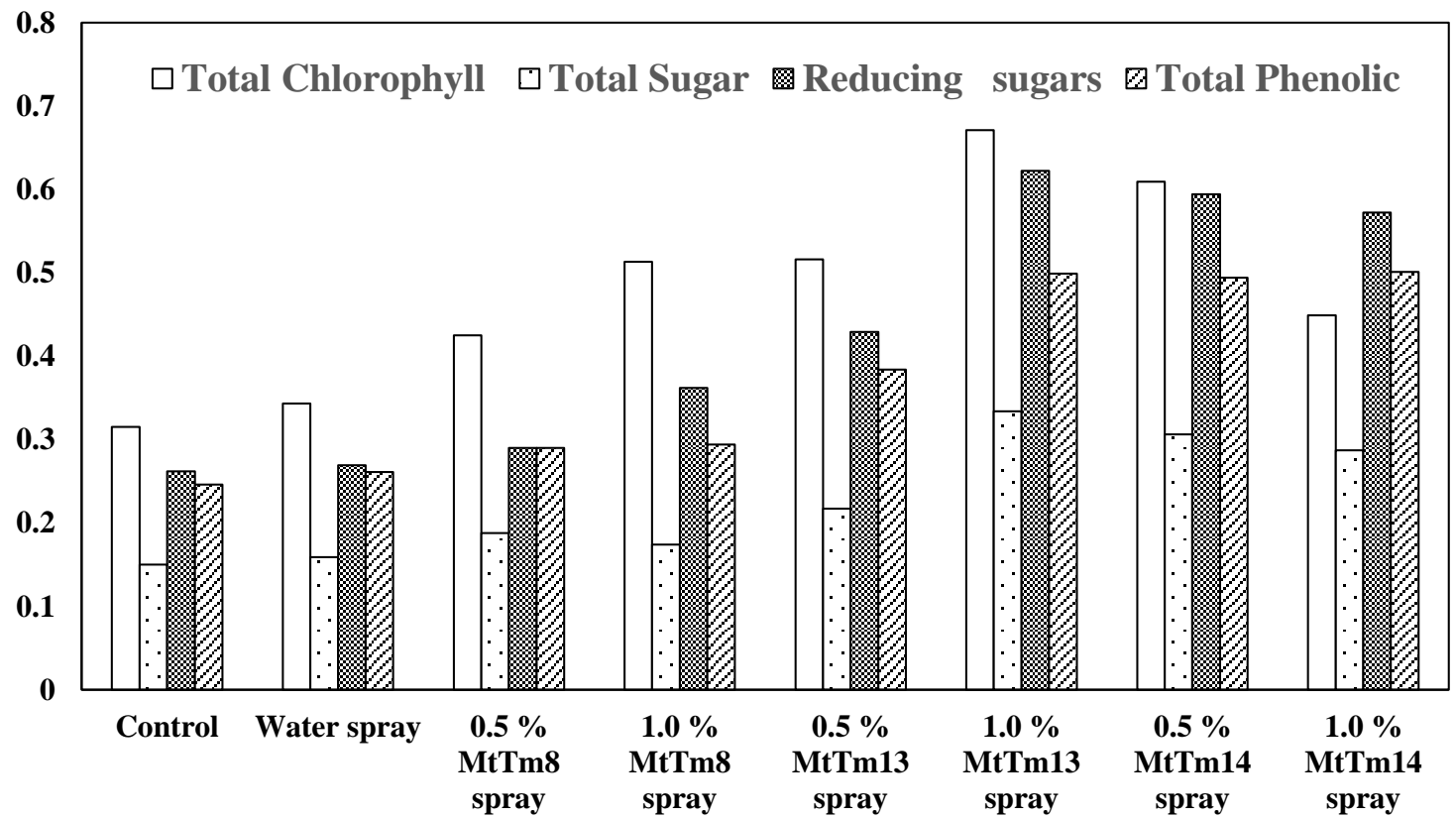

Ten days after seedling growth, treated seeds showed increased shoot length and root length. The maximum shoot and root length of $6.83 \mathrm{~cm} \mathrm{plant}^{-1}$ and $4.83 \mathrm{~cm}$ plant $^{-1}$ was observed in $1.0 \%$ treated seeds with Mt-Tm-
13. From the Methylobacterium treated seedlings, an average of $21 \%$ and $20 \%$ increase in fresh weight and dry weight was observed over the uninoculated control seedlings (Table 3). The bioinoculant 
Methylobacterium treated seedlings also showed better vigor index over the control treatments.

\section{Effect of Methylobacterium application on tomato plant growth and yield}

Under the green house condition, the foliar application of Methylobacterium had significantly improved the overall performance of the tomato plant growth and yield over uninoculated plants (Table 4). Effect of foliar application of Methylobacterium isolate Mt-Tm-13 at 1\% concentration showed significant increase in plant height and yield followed by $1 \%$ foliar spray of Mt-Tm-8. The vast majority of microbes in the phyllosphere exerts no negative influence on plant growth and development and, in fact, often confer a positive effect (Bulgarelli et al., 2013). The significant difference in plant height at different stages were noticed. The maximum plant height of $97.55 \mathrm{~cm} \mathrm{plant}^{-1}$ and root length of $62.68 \mathrm{~cm}^{\text {plant }}{ }^{-1}$ was observed in Mt-Tm-13 treated plants with $1 \%$ concentration. The increased growth could be attributed to the growth hormones like IAA and cytokinin produced by Methylobacterium which stimulated cell division, cell enlargement and influence root morphology. This in return, would have improved assimilation of nutrients. Increase in yield component may also be attributed due to increase in fruit weight as a result of improvement in adequate plant nutrition uptake. As already mentioned before, PPFMs are frequently found on leaf surfaces. Abanda-Nkpwatt et al., (2006) reported about a Methylobacterium extorquens strain that promotes growth of various plant seedlings. Cytokinins stimulate a plant's cell division, vascular cambium sensitivity, and vascular differentiation and induce the proliferation of root hairs, but inhibit lateral root formation and primary root elongation. Liu et al., (2013) reported that the oriental Thuja seedlings inoculated with cytokinin-producing Bacillus subtilis strains were more resistance to stress.

Significant variation was recorded among different treatment combinations for yield attributing characters. Among the different Methylobacterium isolates, plants treated with Mt-Tm-13 had maximum number of fruits (8.8 number plant $\left.{ }^{-1}\right)$. The other isolates also had better yield response when compared to control. The increase in number of fruit per plant is due to increase in individual weight of the fruit which inturn has influenced the overall the yield of the crop.

Similarly, relative water content and leaf proline content were found to be higher in the plants treated with Methylobacterium isolate Mt-Tm-13 (Figure 1). Physiological parameters such as chlorophyll and sugar content were higher in Mt-TM-13 isolate applied plants (Figure 2).

In this study, the Methylobacterium spp. strains enhanced the plant growth parameters of tomato under in vitro condition by secreting significant amount of cytokinin (zeatin) in their culture media as is evident from HPLC analysis which ranged from 0.11 $\mu \mathrm{g} \mathrm{ml}^{-1}$ to $4.94 \mu \mathrm{g} \mathrm{ml}^{-1}$ and this was earlier reported for Bacillus subtilis (1.2 mg. $\mathrm{1}^{-1}$ ) (Arkhipova et al., 2007), Azotobacter vinelandii $\left(0.75 \mu \mathrm{g}^{-1}\right)$. In addition to zeatin, Methylobacterium isolates also produce significant amounts of kinetin and benzyl adenine purine (BAP). The kinetin and BAP phytohormones produced by Methylobacterium sp. is an evidence in improving the plant growth parameters but their exact mechanism with respective gene identification is further needed. The level of cytokinin production by the bacterial strains showed positive effect on tomato seedling growth. This may be contributed by several authors that, methylobacteria can also 
produce other phytohormones rather than zeatin and this assumption was proven in the present study. In most cases, these phytohormones are believed to be changing their assimilate partitioning patterns in plant system which results in bigger and more branched root with greater surface area (Vessey, 2003). Evidence for the role of phytohormone synthesis of auxin, cytokinin and also ACC deaminase (Madhaiyan et al., 2006) by Methylobacterium sp. and its plant growth promoting activity from the studies of Holland (1997) showed this genera can be exploited for its endophytic association and diazotrophic property (Sy et al., 2001).

Current study showed the positive impacts of Methylobacterium on growth and yield of tomato plant compared to control. In addition to foliar spray introduction of Methylobacterium through tomato seeds before planting is easy and cost effective method to improvement seedling and plant growth efficiency. These results proved that plant growth regulators produced by Methylobacterium species could also play a critical role in plant growth promotion.

More understanding is currently provided through mechanism-based studies, and using ecological, genetic and '-omics' approaches. Despite this effort currently carried out by an increasing number of research teams, several questions and hypothesis should still be put on the table and contrasted (Stéphane et al., 2016). Studies on the role of PGP traits on plant bacterial interaction may reveal how this growth promoting traits producing bacteria helps in plant growth. Several studies related to epiphytes are, moreover, mostly biased by experimental models evaluated under gnotobiotic conditions, that is, far away from natural conditions. We need to move beyond and to analyze how the whole plant and its associated phyllosphere microbiota interact for symbiotic association.

\section{References}

Abanda-Nkpwatt, D., Müsch, M. Tschiersch, J. Boettner, M., and Schwab, W. 2006. Molecular interaction between Methylobacterium extorquens and seedlings: growth promotion, methanol consumption, and localization of the methanol emission site. J. Exp. Bot., 57: 4025-4032.

Abdul-Baki, A. A., and Anderson, I.O. 1973. Vigour determination in soybean seed by multiple criteria. Crop Sci., 13:630-633.

Ahmad, F., Ahmad, I., and Khan, M.S. 2008. Screening of free-living rhizospheric bacteria for their multiple plant growth promoting activities. Microbiol. Res., 163:173-181

Andreote, F.D., Azevedo, J.L., and Araújo, W.L. 2009. Assessing the diversity of bacterial communities associated with plants. Brazilian J. Microbiol., 40:417-432.

Andrews, J.H., and Harris, R.F. 2000. The ecology and biogeography of microorganisms on plant surfaces. Annu. Rev. Phytopathol., 38:145-180.

Arkhipova, T.N. Prinsen, E.A. Veselov, S.U. Martynenko, E,V. Melentiev, A.I., and Kudoyarova, G.R. 2007. Cytokinin producing bacteria enhance plant growth in drying soil. Plant Soil., 292:305-315.

Bulgarelli, D., Schlaeppi, K. Spaepen, S. van Themaat, E.V.L., and Schulze-Lefert, P. 2013. Structure and functions of the bacterial microbiota of plants. Ann. Rev. Plant Biol., 64: 807-838.

Callan, N.W., Mathre, D.E., and Miller, J.B. 1990. Bio-priming seed treatment for biological control of Pythium ultimum pre emergence damping off in sh2 sweet corn. Plant Disease., 74: 368-372.

Chagnon, P.L., Bradley, R.L. Maherali, H., and Klironomos, J.N. 2013. A trait-based framework to understand life history of mycorrhizal fungi. Trends in Plant Sci., 18:484-491.

Doronina, N.V., Ivanova, E.G., and Trotsenko, Y.A. 2002. New evidence for the ability of methylobacteria and methanotrophs to synthesize auxins. Microbiol., 71:116-118.

Doronina, N.V., Trostsenko, Y.A. Kuznetsov, 
B.A. Tourova, T.P., and Salkinoja-Salonen, M.S. 2002. Methylobacterium suomiense sp. nov. and Methylobacterium lusitanum sp. nov., aerobic, pink pigmented, facultatively methylotrophic bacteria. Int. J. Syst. Evol. Microbiol., 52:773-776.

Durán, P., Acuña, J.J. Jorquera, M.A. Azcón, R. Paredes, C. Rengel, Z., and de la Luz Mora, M. 2014. Endophytic bacteria from selenium-supplemented wheat plants could be useful for plant-growth promotion, biofortification and Gaeumannomyces graminis biocontrol in wheat production. Biol. Fertil. Soils., 50:983-990.

Glick, B.R., Karaturovic, D.M., and Newell, P.C. 1995. A novel procedure for rapid isolation of plant growth promoting Pseudomonas. Can. J. Microbiol., 41:533-536.

Holland, M.A. 1997. Occams razor applied to hormonology. Are cytokinins produced by plants? Plant Physiol., 115:865-868.

Hornschuh, M., Grotha, R., and Kutschera, U. 2002. Epiphytic bacteria associated with the bryophyte Funaria hygrometrica: effects of Methylobacterium strains on protonema development. Plant Biol., 4:682-687.

Ivanova, E.G., Doronina, N.V., and Trotsenko, Y.A. 2001. Aerobic methylobacteria are capable of synthesizing auxins. Microbiol., 70(4): 392-397.

Jourand, P., Giraud, E. Béna, G. Sy, A. Willems, A. Gillis, M. Dreyfus, B., and de Lajudie, P. 2004. Methylobacterium nodulans sp. nov., for a group of aerobic, facultatively methylotrophic, legume root-noduleforming and nitrogen-fixing bacteria. Int. J. Syst. Evol. Microbiol., 54(6): 2269-2273.

Kavamura, V.N., Santos, S.N. Silva, J.L. Parma, M.M. Avila, L.A. Visconti, A. Zucchi, T.D. Taketani, R.G. Andreote, F.D., and Melo, I.S. 2013. Screening of Brazilian cacti rhizobacteria for plant growth promotion under drought. Microbiol. Res., 168:183191.

Knief, C., Frances, L., and Vorholt, J.A. 2010. Competitiveness of diverse Methylobacterium strains in the phyllosphere of Arabidopsis thaliana and identification of representative models, including $M$. extorquens PA1. Microb. Ecol., 60(2): 440-452.
Koch, A. L. 1994. Growth measurement. In: Gerhardt, P. (Ed.), Methods for General and Molecular Bacteriology. American Society of Microbiology, Washington, DC, USA. pp. $248-277$

Lacava, P.T,, Araujo, W. L. Marcon, J. Maccheroni Jr., W., and Azevedo, J.L. 2004. Interaction between endophytic bacteria from citrus plants and the phytopathogenic bacteria Xylella fastidiosa, causal agent of citrus-variegated chlorosis. Lett. Appl. Microbiol., 39 (1): 55-59.

Lambais, M.R., Crowley, D.E. Cury, J.C. Bull, R.C., and Rodrigues, R.R. 2006. Bacterial diversity in tree canopies of the Atlantic forest. Sci., 312: 1917.

Lambrecht, M., Okon, Y. Vande Broek, A., and Vanderleyden, J. 2000. Indole-3-acetic acid: a reciprocal signalling molecule in bacteria plant interactions. Trends Microbiol., 8:298-300.

Liu, F., Xing, S., and Ma, H. 2013. Cytokininproducing, plant growth-promoting rhizobacteria that confer resistance to drought stress in Platycladus orientalis container seedlings. Appl. Microbiol. Biotechnol., 97: 9155-9164.

Loaces, I., Ferrando, L., and Scavino, A.F. 2011. Dynamics, diversity and function of endophytic siderophore-producing bacteria in rice. Microb. Ecol., 61: 606-618.

London Hahlbrock, K., Bednarek, P. Ciolkowski, I. et al., 2003. Non-self recognition, transcriptional reprogramming, and secondary metabolite accumulation during plant/pathogen interactions. Proc. Nat. Acad. Sci., 100 (24):14569-14576.

Long, H.H., Schmidt, D.D., and Baldwin, I.T. 2008. Native bacterial endophytes promote host growth in a species-specific manner; phytohormone manipulations do not result in common growth responses. PLOS ONE, 3(7): e2702.

Madhaiyan, M., Poonguzhali, S. Senthilkumar, M. Lee, J.S., and Lee, K.C. 2012. Methylobacterium gossipiicola sp. nov., a pink pigmented, facultatively methylotrophic bacterium isolated from the cotton phyllosphere. Int. J. Syst. Evol. Microbiol., 62 (1): 162-167.

Madhaiyan, M., Poonguzhali, S., and Sa, T. 2007. 
Characterization of 1-aminocyclopropane1- carboxylate (ACC) deaminase containing Methylobacterium oryzae and interactions with auxins and ACC regulation of ethylene in canola (Brassica campestris). Planta., 226(4): 867-876.

Madhaiyan, M., Suresh Reddy, B.V. Anandham, R. et al., 2006. Plant growth-promoting Methylobacterium induces defense responses in groundnut (Arachis hypogaea L.) compared with rot pathogens. Curr. Microbiol., 53 (4) : 270-276.

Mahajan, G., and Singh, K.G. 2006. Response of greenhouse tomato to irrigation and fertigation. Agri. Water Managt., 84: 202206.

Mastouri, F., Bjorkman, T., and Harman, G.E. 2010. Seed treatment with Trichoderma harzianum alleviates biotic, abiotic, and physiological stresses in germinating seeds and seedlings. Phytopathol., 100(11): 12131221.

Meena, K.K., Kumar, M. Kalyuzhnaya, M.G. et al., 2012. Epiphytic pink-pigmented methylotrophic bacteria enhance germination and seedling growth of wheat (Triticum aestivum) by producing phytohormone. Antonie van Leeuwenhoek, Int. J.Gen. Mol.Microbiol., 101(4): 777786.

Moeinzadeh, A., Sharif-Zadeh, F. Ahmadzadeh, M., and Tajabadi, F.H. 2010. Biopriming of sunflower (Helianthus annuus L.) seed with Pseudomonas fluorescens for improvement of seed invigoration and seedling growth. Australian J. Crop Sci., 4(7): 564-570.

Montañez, A., Blanco, A.R. Barlocco, C. Beracochea, M., and Sicardi, M. 2012. Characterization of cultivable putative endophytic plant growth promoting bacteria associated with maize cultivars (Zea mays L.) and their inoculation effects in vitro. Appl. Soil Ecol., 58: 21-28.

Omer, Z.S., Tombolini, R. Broberg, A., and Gerhardson, B. 2004. Indole-3-acetic acid production by pink-pigmented facultative methylotrophic bacteria. Plant Growth Regul., 43(1): 93-96.

Penrose, D.M., and Glick, B.R. 2003. Methods for isolating and characterizing ACC deaminase-containing plant growth- promoting rhizobacteria. Physiol. Plantarum., 118(1): 10-15.

Philippot, L., Raaijmakers, J. Lemanceau, M. Putten, P., and van der,W.H. 2013. Going back to the roots: the microbial ecology of the rhizosphere. Nature Rev. Microbiol., 11: 789-799.

Pirttila, A., Joensuu, M. Pospiech, P. Jalonen, H., and Hohtola, A. 2004. "Bud endophytes of Scots pine produce adenine derivatives and other compounds that affect morphology and mitigate browning of callus cultures. Physiologia Plantarum., 121(2): 305-312.

Pirttilä, A.M., Laukkanen, H. Pospiech, M. Myllylä, R., and Hohtola, A. 2005. Detection of intracellular bacteria in the buds of Scotch pine (Pinus sylvestris L.) by in situ hybridization. Appl. Environ. Microbiol., 66(7): 3073-3077.

Quilambo, O.A., 2004. Proline content, water retention capability and cell membrane integrity as parameters for drought tolerance in two peanut cultivars. S. Afr. J. Bot., 70(2): 227-234

Rashid, S., Charles, T.C., and Glick, B.R. 2012. Isolation and characterization of new plant growth-promoting bacterial endophytes. Appl. Soil. Ecol., 61: 217-224.

Raymond, J., Siefert, J.L. Staples, C.R., and Blankenship, R.E. 2004. The natural history of nitrogen fixation. Mol. Biol. Evol., 21: 541-554.

Reinhold-Hurek, B., Hurek, T. Claeyssens, M., and Van Montagu, M. 1993. Cloning, expression in Escherichia coli, and characterization of cellulolytic enzymes of Azoarcus sp., a root-invading diazotroph. $J$. Bacteriol., 175:7056-7065.

Rossetto, P. B., Dourado, M. Quecine, C.et al., 2011. Specific plant induced biofilm formation in Methylobacterium species. Brazilian J. Microbiol., 42(3): 878-883.

Saxena, A.K., Lata Shende, R., and Pandey, A.K. 2005. Culturing of plant growth promoting rhizobacteria. In: Basic research applications of mycorrhizae. (Eds) Gopi, K.P, Varma, A. I K International Pvt Ltd, New Delhi, pp 453-474.

Schauer, S., and Kutschera, U. 2011. A novel growth-promoting microbe, Methylobacterium funariae sp. nov., 
isolated from the leaf surface of a common moss. Plant Signaling and Behavior., 6 (4) : 510-515.

Schwyn, B., and Neilands, J. 1987. Universal chemical assay for the detection and determination of siderophores. Analytical Biochem., 160: 47-56.

Senthilkumar, M., Madhaiyan, M. Sundaram, S.P., and Kannaiyan, S. 2009. Intercellular colonization and growth promoting effects of Methylobacterium sp. with plant-growth regulators on rice (Oryza sativa L. Cv CO43). Microbiol. Res., 164: 92-104.

Shen, M., Kang, Y.J. Wang, H.L. Zhang, X.S. Zhao, Q.X. 2012. Effect of plant growthpromoting rhizobacteria (PGPRs) on plant growth, yield, and quality of tomato (Lycopersicon esculentum Mill.) under simulated seawater irrigation. J. Gen. Appl. Microbiol., 58: 253-262

Sheng, H.M., Gao, H.S. Xue, L.G. Ding, S. Song, C.L. Feng, H.Y. and An, L.Z. 2011. Analysis of the composition and characteristics of culturable endophytic bacteria within sub nival plants of the Tianshan mountains. Northwestern China. Curr. Microbiol., 62: 923-932.

Stéphane, C., Saikkonen K., Mitter B., Campisano A., and Mercado-Blanco. J., 2016. Editorial special issue: Soil, Plants and Endophytes.
Plant Soil., 405:1-11

Sy, A., Giraud, E. Jourand, P. et al., 2001..Methylotrophic Methylobacterium bacteria nodulate and fix nitrogen in symbiosis with legumes. J. Bacteriol., 183(1): 214-220.

Sy, A., Timmers, A.C. Knief, C., and Vorholt, J.A. 2005. Methylotrophic metabolism is advantageous for Methylobacterium extorquens during colonization of Medicago truncatula under competitive conditions. Appl. Environ. Microbiol., 71: 7245-7252.

Thompson, I.P., Bailey, M.J. Fenlon, J.S. Fermor, T.R. Lilley, A.K. Lynch, J.M. et al., 1993. Quantitative and qualitative seasonal changes in the microbial community from the phyllosphere of sugar beet (Beta vulgaris). Plant Soil, 150: 177-191.

Vessey, K.V. 2003. Plant growth promoting rhizobacteria as biofertilizers. Plant Soil, 255: 571-586.

Warren, J.E, and Bennett, M.A. 1999. Bioosmopriming tomato Lycopersicon esculentum Mill. seeds for improved stand establishment. Seed Sci. Technol., 27: 489499.

\section{How to cite this article:}

Senthilkumar, M. and Krishnamoorthy, R. 2017. Isolation and Characterization of Tomato Leaf Phyllosphere Methylobacterium and their Effect on Plant Growth. Int.J.Curr.Microbiol.App.Sci. 6(11): 2121-2136. doi: https://doi.org/10.20546/ijcmas.2017.611.250 